ppi $201502 Z U 4645$

Esta publicación cientifica en formato digital es continuidad de la revista impresa ISSN-Versión Impresa 0798-1406 / ISSN-Versión on line 2542-3185Depósito legal pp

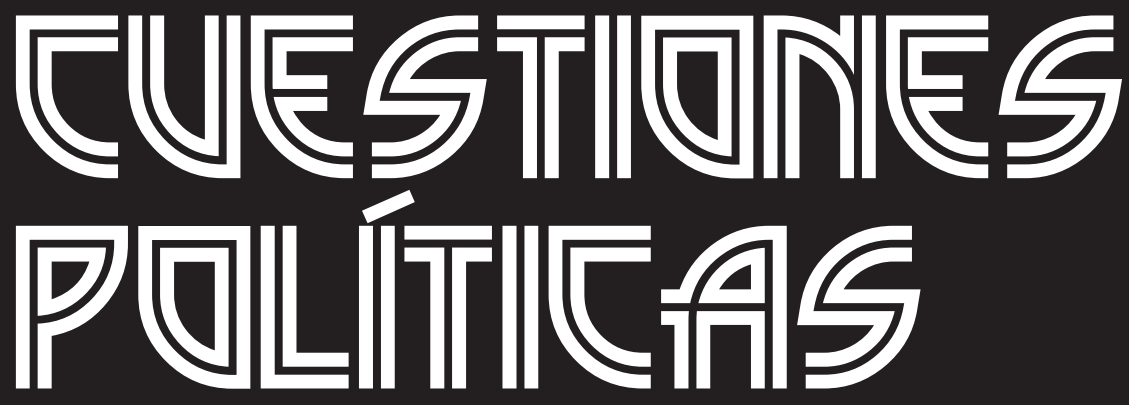

Instituto de Estudios Políticos y Derecho Público "Dr. Humberto J. La Roche' de la Facultad de Ciencias Jurídicas y Políticas de la Universidad del Zulia Maracaibo, Venezuela
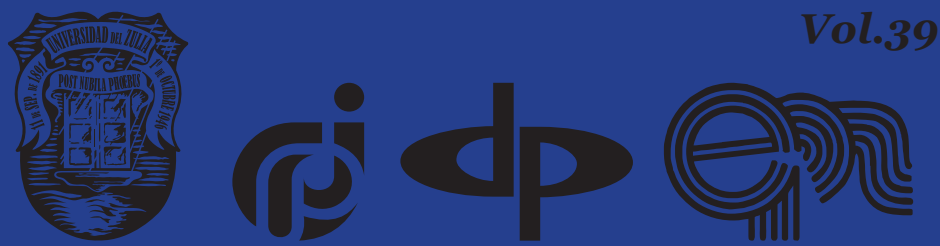


\title{
Role of principles of law from the perspective of legal impact in modern Russia: theoretical and technical-legal aspects
}

\author{
DOI: https://doi.org/10.46398/cuestpol.3968.52
}

\author{
Gyulnaz Eldarovna Adygezalova * \\ Irina Stanislavovna Kich ** \\ Sergey Alekseevich Zhinkin *** \\ Susanna Vladimirovna Salikova ${ }^{* * *}$ \\ Neonila Dmitrievna Paltseva *****
}

Abstract

Thearticlediscussestheproblems related totheimplementation of the legal impact on modern Russia and the role of the principles of law as the underlying idea behind that impact. This research aims to structure visions of the main characteristics and classifications of the principles of law in the context of their formalization. The authors use the method of technical analysis of regulations, which is important to meet the requirements of legal engineering. As a result of the work carried out, the authors suggest that, on the one hand, it is important to aim at the standardization of the principles of law as accurately and accurately as possible in legislation. On the other hand, they assume that principles that are already assured in legislation but have not yet been recognized by the scientific community must also obtain an assessment and justified characteristics in the doctrine. They conclude that, from a technical-legal point of view, a principle of law that is not scientifically recognized does not disappear from the legal framework if it is institutionalized as such in effective legislation. On the contrary, essentially new principles enshrined in legislation should not be ignored by legal science.

Keywords: legal science; principles of law; law in modern Russia; theoretical aspects of law; technical-legal aspects of the law.

* Kuban State University, Krasnodar, Russia. ORCID ID: https://orcid.org/oooo-0oo3-3682-2121. Email: gyulnaz_200o@mail.ru

** Kuban State University, Krasnodar, Russia. ORCID ID: https://orcid.org/oooo-ooo3-2995-2163. Email: irina.kich@bk.ru

*** Kuban State University, Krasnodar, Russia. ORCID ID: https://orcid.org/oooo-ooo2-0291-4469. Email: sergey.zhinkin@bk.ru

**** Kuban State University, Krasnodar, Russia. ORCID ID: https://orcid.org/oooo-0oo2-0224-0388. Email: susanna.salikova@bk.ru

****** Kuban State University, Krasnodar, Russia. ORCID ID: https://orcid.org/oooo-0oo2-4691-0284. Email: n.d.paltseva@mail.ru 


\section{Papel de los principios del derecho desde la perspectiva del impacto legal en la Rusia moderna: aspectos teóricos y técnico-legales}

\section{Resumen}

El artículo analiza los problemas relacionados con la implementación del impacto legal en la Rusia moderna y el papel de los principios del derecho como la idea subyacente detrás de dicho impacto. Esta investigación tiene como objetivo estructurar las visiones sobre las principales características y clasificaciones delos principios del derecho en el contexto desuformalización. Los autores utilizan el método de análisis técnico de las regulaciones, que es importante para cumplir con los requisitos de la ingeniería legal. Como resultado del trabajo realizado, los autores sugieren que, por un lado, es importante apuntar a la estandarización de los principios del derecho con la mayor precisión y especificación posible en la legislación. Por otro, asumen que los principios que ya están asegurados en la legislación pero que aún no han sido reconocidos por la comunidad científica, también deben obtener una evaluación y características justificadas en la doctrina. Concluyen que, desde el punto de vista técnico-jurídico, un principio de derecho que no está científicamente reconocido no desaparece del marco jurídico si se institucionaliza como tal en la legislación efectiva. Por el contrario, los principios esencialmente nuevos consagrados en la legislación no deben ser ignorados por la ciencia jurídica.

Palabras clave: ciencia jurídica; principios de derecho; derecho en la Rusia moderna; aspectos teóricos del derecho; aspectos técnico-legales del derecho.

\section{Introduction}

In the modern world, legal impact and its technical components are influenced by several factors and characterized by unprecedented complexity. In this context, the legal and technical need for clear and precise statutorization of the principles of law and principles of legal impact as its fundamentals, which should form the core of legal regulation, is growing.

In Russian science, the issues connected with characteristics and classification of the principles of law remain a subject of discussion. Participants of such discussions point out that the principles of law are always objectively inherent in law as a phenomenon and social regulator, "the essence of law penetrates the content of all its principles" (Vedyakhin and Surkova, 2005). As Jean-Louis Bergel fairly noted, "general principles of law constitute a foundation without any legal framework" (Vedyakhin and Vedyakhina, 2002). According to the interpretations suggested by 
Gyulnaz Eldarouna Adygezalova, Irina Stanislavovna Kich, Sergey Alekseevich Zhinkin, Susanna Vladimirovna Salikova y Neonila Dmitrievna Paltseva

modern authors, the principles of law "represent the ideas that express the essence of law and characterize its social purpose" (Vedyakhin and Vedyakhina, 2002).

Unfortunately, from this perspective, the situation in modern Russia is very chaotic in terms of technical-legal aspects. The doctrine contains one set of general legal principles of law; a similar but still different set is enshrined in the federal legislation; the third one -in the regional set of laws; the fourth one -in the acts issued by the Supreme Court of the Russian Federation and the Constitutional Court of the Russian Federation. One the one hand, it should be admitted that such a situation exists; on the other hand, it appears unacceptable not only from the technical but also from the legal and social perspectives even though in the course of examination of certain cases, the court spreads general moral definitions that make up the reasonable content of law among the mass of the population (Lavrus, 2005).

This article looks at the issue of classification of principles of law and distinguishing principles as such and doctrinal ideas applying to the legal sphere. Besides, this work pursues the goal of showing that the principles enshrined in the federal and regional legislation of modern Russia are not the same; therefore, they must be unified and brought into correlation.

\section{Methods}

For making a more accurate distinction between the principles of law and ordinary ideas connected with improvement of social and legal life and shared by well-known scholars, it appears reasonable to use technical analysis of texts of regulations. In our opinion, it is also important to use the comparative method to compare the principles enshrined in the federal and regional legislation and provide comparative characteristics of statutory and non-statutory principles.

\section{Results}

As a result, we identified three groups of principles recognized as the principles of law: those that are doctrinal, those that are enshrined in the federal and regional legislation, and those enshrined in the acts issued by the Supreme Court of the Russian Federation and the Constitutional Court of the Russian Federation. In this connection, we also examined the issue of their correlation and harmonization. 


\section{Discussion}

According to R.Z. Livshits, the principles of law permeate the whole of legal matter - the ideas, norms, and relations - and endow it with logic, consistency, and balance (Livshits, 1994), which is significant from the legal and technical perspectives. However, it happens only if the mechanism of implementation of the corresponding principle has been formed. As noted by representatives of the American socio-legal theory, the principles of law are developed in the course of legal activity and determine the directions of legal practice (Adygezalova, 2017). In this respect, the task of developing such mechanisms of implementation, including information, educational, organizational, and legal means, is gaining relevance.

The principles express the essence of law (social, value, etc.) directly, defining and specifying its general concept. It is the principles that should underlie specific regulatory prescriptions that model the relationships between the subjects of legal relations: "It is the only way to ensure consistency and stability, and, most importantly, the genuine legal nature of regulatory control" (Sidorkin, 2010: 86). At the same time, it should be noted that there is a wide range of opinions as to the very concept of legal principles and the necessity for their practical reinforcement.

For example, V.I. Zazycki reasonably suggests that scientific ideas formulated by scholars and offered as principles of law should be differentiated from those principles that have already been enshrined in legislation (Zazycki, 1996). Indeed, from the technical-legal perspective, before their statutorization, the ideas suggested by scholars and politicians remain only ideas, though advanced and socially valuable.

According to V.M. Vedyakhin, the principles of law are the basic ideas expressing the essence, designation, consistent patterns, and development trends in the Russian law enshrined directly or indirectly in legal regulatory provisions or existing in the legal consciousness of law enforcers (Vedyakhin and Surkova, 2005). In other words, the ideas must be directly or indirectly reflected by the legislation, which is a view that we share. As far as the scholar's statement that the principles of law are contained in legal consciousness is concerned, the very presence of the principles of law in legal consciousness is impossible without receiving the information about such principles by law enforcers primarily from the legislation.

The principles of law along with other "mechanisms of self-regulation (self-organization) in the legal system" (following the terminology suggested by V.V. Sorokin) perform the function of an organization of "control communications", the purpose of which is "to eliminate the internal contradictions on the legal system" (Sorokin, 2004).

It should be noted that the principles of law do not only serve as a kind of reference points in the course of formation and implementation 
Gyulnaz Eldarovna Adygezalova, Irina Stanislavovna Kich, Sergey Alekseevich Zhinkin, Susanna Vladimirovna Salikova y Neonila Dmitrievna Paltseva

of legislation but also: "Exercise both direct and indirect influence on the social relations that represent the subject of legal regulation" (Vedyakhin and Vedyakhina, 2002: 569). Sometimes they are called "the dynamic elements of the legal system" (Skurko, 2008) but this opinion needs to be substantiated. They should rather be viewed as a stabilizing component that guides law-making at the federal and regional levels.

In the context of the need for legislative formalization of the principles of law, the opinion put forth by G.V. Nazarenko, who distinguishes written and unwritten principles, is of interest. They make up two large groups: 1) principles of actual law; 2) other legal principles, which are sometimes called "legal maxims". Through laws, written principles institutionalize the fundamental legal requirements and represent legal means and incentives. Unwritten principles (legal maxims), as an element of legal consciousness, convey the initial legal ideas and influence the character and the degree of implementation of legal means (Vedyakhin and Vedyakhina, 2002). However, in this case, the principles of law are intermingled with legal maxims, which is unacceptable from the technical-legal perspective.

According to S.Yu. Lavrus, principles of law "are either directly outlined in positive law and stated in legal regulations or drawn from the general meaning of legislation and are contained there in a concealed form. The latter include, for example, the principle of correspondence between positive law and natural law, the principle of combination of liabilities and rights, the principle of combination of incentives and restrictions, the principle of mutual responsibility between a person and state, etc." (Lavrus, 2005). In this connection, it should be stressed once more that it is necessary to differentiate between doctrinal provisions and principles contained in current legislation, which have been formalized in the texts of current regulations. It is hardly possible to encounter cases when law enforcement bodies make an appeal related to "the combination of incentives and restrictions" or "correspondence to natural law" since these ideas represent provisions desirable within a legal system and an ideological benchmark rather than real principles of law.

Ideas of law belong to the area of legal consciousness developed by legal science. However, before they are included in the effective legal norms, either directly or indirectly, they remain only ideas, important theoretical statements that do not have legal significance. If these ideas are mediated by the legislator, they enter the sphere of legal norms and merge with the content of positive law of a certain state as principles of law (Vedyakhin and Vedyakhina, 2002).

In this connection, it appears that if a principle has not been documented in legislation at all, neither directly nor indirectly, it serves not as a principle of law as such but nothing more than a statement of legal science that has a potential for becoming a principle of law and legal impact. Such principles 
as the principle of equality in the eyes of the law and the principle of democratism in law-making have both worked their way from an idea to a principle of effective law.

In a wider sense, the principles of law are interpreted by N.M. Vagina, who points out that by their nature, "principles of law represent fundamental ideas enshrined in various formal sources, as well as those that have not been institutionalized but are widely recognized in consistent legal practice and legal relations" (Vagina, 2004). However, in our opinion, it is important to make a clear distinction between scientific ideas, suggestions connected with legal regulation of different spheres of social life (which represent conclusions made by legal science) and principles of legislation, which represent the first stage of implementation of the principles of law connected with their regulatory legal formalization.

Principles of law are ideas pervading the content of the law as if dissolved in it (Reuf, 2004). For ideas to be implemented as principles of law, they should be formalized and documented in corresponding regulations. It is regulations that will be implemented as principles of effective law. The principles of law determine general focus, high quality, and effectiveness of law-making, law-implementing, interpreting, and lawsystematizing practices in any civilized society (Frolov, 2001), which is important from the technical-legal perspective. They can represent generalizations of the content or implementation of law and aspects of its essence. Therefore, it is essential to institutionalize them at the federal and regional levels and specify them in detail for their uniform understanding and usage.

There is also an opinion that principles exist in the form of guiding ideas of law that are abstracted from the patterns of social development. In this sense, they are: "Significantly ahead of the time when they are formalized in legislation and, therefore, represent a worldview category rather than a regulatory one" (Frolov, 2001: 16). However, as we see it, principles are called principles of law because they are documented in legislation and not just in the worldview of certain scholars. Apart from that, it will always remain unknown how many ideas belonging to such scholars have not been documented anywhere and were simply forgotten over time.

It should be noted that the situation in the legal system of modern Russia unfolds in the following way: the doctrine contains a certain set of general legal principles of law; another set is enshrined in the federal legislation; the third - in the regional set of laws; the fourth in the acts issued by the Plenum of the Supreme Court of the Russian Federation. This situation can be considered to be a flaw in the legal system or a fault in the system of legal impact and can lead to an interference situation, which is unacceptable from the perspective of legal engineering. 
Gyulnaz Eldarovna Adygezalova, Irina Stanislavovna Kich, Sergey Alekseevich Zhinkin, Susanna Vladimirovna Salikova y Neonila Dmitrievna Paltseva

Thus, an essential condition for implementation of the principles of law from the perspective of legal engineering is their legal formalization, transformation into principles of legislation, and institutionalized principles of legal regulation of corresponding spheres of social life. This is the main technical-legal condition for implementation of the principles of law.

The principles of law and development of legislation reside in dialectical unity and mutually stimulate each other (Skurko, 2008). Similarly, the doctrinal statement of a principle encourages its more or less full institutionalization within the legislation. On the other hand, the institutionalization of certain principles in current legislation should at least serve as a reason for their evaluation and analysis from the scientific perspective. In any case, a conflict between principles of law outlined in the doctrine and regulatory provisions documented in effective legislation whose level of generalization suggests that they possess the value of principles is unacceptable.

Lack of legislative documentation of the principles of law makes it hardly possible to implement them in practice as a source of law and leads to discrepancies in their interpretation in the course of application.

Interestingly, in the scientific literature, there is a view according to which: "It is necessary to gradually get rid of those legislative statements that contradict the principles of law" (Lavrus, 2005: 8). However, the following reservations should be made here. First, it refers to generally recognized principles of law that are enshrined in the legislation. If statutory regulations contradict a basic doctrinal idea proclaimed by certain authors as a principle of law, this must not lead to a failure to comply with these regulations since it would constitute a violation of the principle of legality. Second, if a certain idea proclaimed as a principle of law contradicts other principles of law enshrined in legislation, it cannot be recognized as a principle of law; from the technical-legal perspective, changing legislation for the sake of such an idea is simply unacceptable.

As we have found, in legal literature principles of law often serve as a subject of discussion and are viewed primarily as ideas or norms. As it has been fairly noted by A.S. Sidorkin:

When we think of the principles of law as of ideas, we endow them with a purely doctrinal nature, which belittles their role in terms of their practical implementation. Conditioned upon the essence of law, principles initially represent ideas but further on acquire the features of norms. Normativity provides them with practical value as a foundation for developing legislation (Sidorkin, 2010: 13).

In this respect, it should be added that being a specific (fundamental, abstract) legal norm, a principle of law should always be expressed in a certain external form (constitution, law, court ruling, or a doctrine). In this case, such principle starts to be implemented as a legislative principle: a 
general legal one, a cross-sectoral or sectoral principle. From the technicallegal perspective, this is the only way for a principle to be implemented.

As can be seen from the foregoing, there is no agreement among legal theorists as to the criterion of positivity applied to principles of law. While some scholars believe that principles of law should be positively documented in the form of regulations (Mitskevich, 1975; Smirnov, 1977), others think that such principles express the spirit of the law rather than its letter. Therefore, they do not have to be directly articulated in laws and regulations but can result from a set of laws and legislation in general (Livshits and Nikitinskii, 1974).

In our opinion, if we are talking about the effective Russian law as a system of norms gathered in regulations and other sources of law rather than scientific abstract ideas applied to law in general, principles of law must be documented in a more or less detailed way in the form of legal provisions of the effective law. Otherwise, they can only be qualified as an ethical foundation for regulating social life or the basic ideas behind human community rather than principles of law as such. It is not infrequent that the legislator institutionalizes a certain regulatory principle not yet recognized by the doctrine, but it becomes such due to its statutorization. It is an important technical-legal feature of the modern Russian legislation at the federal and regional levels.

Moreover, if a principle of law has not been enshrined in legislation, the following question arises: What is its connection to the actual legal reality? Isn't it an ideological cliché detached from reality? In this respect, we cannot agree with the identification of "super-positive principles of law" in the scientific literature.

We assume that it is necessary to discuss not only statutorization of principles of law as ideas but also doctrinal recognition of the legislative provisions whose level of abstraction suggests that their meaning is equal to that possessed by principles of law. It should be noted that principles enshrined in legislation as such will remain those even without doctrinal recognition.

Understanding principles of law as a manifestation of the spirit of the law raises the question of making a distinction between the principles of law as such serving as a regulator and principles of effective law in a certain sphere of regulated relations. There can be discrepancies and even contradictions between them (for instance, legislative institutionalization of the usage of terror against certain persons during revolutions as a principle of legal impact and state policy is in contradiction with the principles of equality, humanity, social peace, and balance of social interests). From the technicallegal perspective, it is impossible to identify the content of the spirit of the law, which is a subject some authors writing a lot about; there is plenty of room for scientific imagination here. 
Gyulnaz Eldarovna Adygezalova, Irina Stanislavovna Kich, Sergey Alekseevich Zhinkin, Susanna Vladimirovna Salikova y Neonila Dmitrievna Paltseva

It should be added that the very design and identification of the principle of law in science should be primarily oriented at law-making practices at the federal and regional levels and social functioning needs.

The legal system of the Russian Federation is characterized by a situation when a whole range of principles of legal regulation, though having not been recognized by legal science, have been institutionalized in federal and regional legislation, acts issued by the Constitutional Court of the Russian Federation and the Plenum of the Supreme Court of the Russian Federation. For example, it has been noted in specialized literature that the Constitutional Court of the Russian Federation has repeatedly deduced principles of law from the Constitution of the Russian Federation that are not directly institutionalized in it, such as the principle of proportionality, the principle of legal certainty, and the principle of maintaining citizens' trust in law and government actions (the principle of respect for legitimate expectations) (Vedyakhin and Surkova, 2005). As we see, these principles have not been directly outlined in the legislation. Apart from that, they have not received support from legal science and have not even become a subject of scientific discussion.

It should be highlighted that a set of principles of regional legislation (principles of positive law) have been developed and institutionalized within regional law-making. Let us try to identify those foundations of legal regulation of major spheres of social relations that have been enshrined in legislation but are not recognized as principles of law by legal science.

One of the principles of law specified in specialized literature is consistency, uniformity of legal regulation at the federal and regional levels. We assume that consistency acts not only as a principle of law but also as a principle of its formation and functioning, in other words, as a general legal principle of law. This is not only a doctrinal view, although the unity of legal space as a phenomenon and guidepost have already drawn the interest of Russian scholars (Azizova, 2004; Filippov, 2013).

The thing is that consistency is institutionalized in the current legislation of a few subjects of the Russian Federation as a principle underlying the very design of regulations. Let us provide only two examples. Article 4, paragraph 1 of the Law of the Republic of North Ossetia-Alania of 14 November 2014 no. 36-RZ "On laws and regulations of the Republic of North Ossetia-Alania" says that "laws and regulations effective the Republic of North Ossetia-Alania form an integral system of laws and regulations of the Republic of North Ossetia-Alania arranged by their legal force (legislation of the Republic of North Ossetia-Alania)" (The Law of the Republic of North Ossetia-Alania № 36-RZ, 2014). The Law of Krasnodar Krai "On law-making and laws and regulations of Krasnodar Krai" of 6 June 1995 states that "laws and regulations of the region form in their entirety a unified, integral, and differentiated normative legal system - the legislation of Krasnodar Krai” (The Law of Krasnodar Krai № 7-KZ, 1995). 
The Law of the Kabardino-Balkarian Republic of 3 August 2002 no. 52-RZ (as amended on 5 June 2018) "On legal acts of the KabardinoBalkarian Republic" proclaims consistency as a principle of law-making (The law of Kabardino-Balkarian Republic № 52-RZ, 2002). Interestingly, this regulation also mentions such law-making principles as unity and consistency of the system of law and regulations, timely adoption of laws, comprehensiveness of legal regulation, and commitment to creating mechanisms of implementation of legal acts. It appears that the abovementioned principles are not only and not so many principles of lawmaking as principles of legal regulation of social life, i.e. principles of law by their nature, which at the same time apply to the requirement of legal engineering.

The following principle that has been included in the regional legislation in much detail is the principle of respect for ethnic and cultural identity. Incidentally, the principle of respect for identity has been enshrined in international documentation and national legislation for a long time even though it is not identified as a principle of law in Russian literature. For example, Article 21 of the Convention on Human Rights and Fundamental Freedoms of the Commonwealth of Independent States (Ratified by the Federal Law no. 163-FZ of 4 November 1995) has institutionalized that "persons belonging to national minorities shall not be denied the right, either individually or collectively, to express, preserve and develop, without hindrance, their ethnic, linguistic, cultural or religious identity" (The Convention on Human Rights and Fundamental Freedoms of the Commonwealth of Independent States, 1995).

Importantly, this principle has been also manifested in the legislation of the subjects of the Russian Federation. Given the restricted length of the article, we will provide only two examples. Article 3 of the Constitution of the Republic of Ingushetia proclaims "preservation and protection of the historical and cultural legacy of peoples and their national identity" the supreme goal of the state (The Constitution of the Republic of Ingushetia, 1994). Article 5 of the Law of the Republic of Kalmykia "On culture" says that: "The state policy in the sphere of culture in the Republic of Kalmykia is implemented under several principles, including the central role of culture in development and personal self-fulfillment, humanization of society, and preservation of national identity" (The Law of the Republic of Kalmykia № 381-lll-3, 2007).

In some cases, in regional legislation, the principle of national identity is included along with the principle of equality between the peoples living within the territory of the corresponding subject. For instance, the Constitution of the Kabardino-Balkarian Republic of 1 September 1997 says that "the Kabardino-Balkarian Republic is based on the principle of unity of the equal peoples of Kabardino-Balkaria" (The Constitution of the 
Gyulnaz Eldarouna Adygezalova, Irina Stanislavovna Kich, Sergey Alekseevich Zhinkin, Susanna Vladimirovna Salikova y Neonila Dmitrievna Paltseva

Kabardino-Balkarian Republic № 28-RZ, 1997). Similar prescriptions can be found in the acts of other subjects of the Russian Federation.

A constituent part of the implementation of this principle is statutorization of the legal protection of national languages as an integral element of national culture.

From this perspective, suggestions of some authors are of interest. They believe that it is necessary to develop so-called ethno-cultural education (Zagirov, 2017) focused on the preservation of ethno-cultural identity of people by introducing them to the native culture, national language, and traditions of the corresponding ethnic group together with their exposure to the most significant values of world culture.

\section{Conclusion}

Let us draw conclusions from our research. Today, from the technicallegal perspective, a principle of law that is not scientifically recognized does not disappear from the legal framework if it is institutionalized as such in the effective legislation. On the contrary, essentially new principles enshrined in regional legislation (such as the uniform character (consistency) of regulation at the federal and regional levels, preservation of ethnic and cultural identity, etc.) should not be ignored by legal science; instead, they should become a subject of doctrinal analysis and justified scientific evaluation.

From the technical-legal perspective, for their effective implementation, it is necessary to ensure the most comprehensive, accurate, and unambiguous institutionalization of fundamental ideas connected with legal regulation in normative and legal prescriptions, which should be formulated clearly and precisely and, whenever necessary, provide their detailed normative characteristics.

\section{Bibliographic References}

ADYGEZALOVA, Gyulnaz Eldarovna. 2017. "Sociological jurisprudence of the United States in the XX century: the formation of doctrine, the development and improvement of the rule of law" In: Abstract of a thesis for an Advanced Doctoral degree in Law. Krasnodar, Russia.

AZIZOVA, Viktoriya Timurovna. 2004. General theoretical problems of ensuring a unified legal space in the Russian Federation: Abstract of a Ph.D. thesis in Law. Makhachkala, Russia. 
FILIPPOV, Aleksandr Nikolaevich. 2013. Constitutional and legal mechanism for ensuring the unity of the legal space of the Russian Federation: Abstract of a Ph.D. thesis in Law. Kazan, Russia.

FROLOV, Sergey Evgenievich. 2001. Principles of law (questions of theory and methodology): Abstract of a Ph.D. thesis in Law. Nizhnii Novgorod, Russia.

LAVRUS, S.Y. 2005. Implementation of the principles of law in legal practice: Abstract of a Ph.D. thesis in Law. Kazan, Russia.

LIVSHITS, R.Z. 1994. Theory of law. Norma. Moscow, Russia.

LIVSHITS, R.Z., NIKITINSKY, V.I. 1974. "Principles of Soviet labor law" In: Soviet state and law. No. 8, pp. 89-100.

MITSKEVICH, A.V. 1975. "Soviet socialist law, its basic principles and system" In: Soviet state and law. No. 9, pp. 128-139.

REUF, Vladislav Markovich. 2004. Special-legal principles of law: Abstract of a $\mathrm{Ph} . \mathrm{D}$. thesis in Law. Volgograd, Russia.

SIDORKIN, Aleksander Sergeevich. 2010. Principles of law: concept and implementation in Russian legislation and judicial practice: Abstract of a Ph.D. thesis in Law. Moscow, Russia.

SKURKO, E.V. 2008. Principles of law. Norma. Moscow, Russia.

SMIRNOV, O.V. 1977. "Correlation of norms and principles in Soviet law" In: Soviet state and law. No. 2., pp. 14-26.

SOROKIN, Vitaly Viktorovich. 2004. General doctrine of the legal system of the transition period. Moscow, Russia.

THE CONSTITUTION OF THE KABARDINO-BALKARIAN REPUBLIC № 28-RZ. 1997. (September 1, 1997). Available online. In: docs.cntd.ru/ document/720705883. Consultation date: 12/04/2020.

THE CONSTITUTION OF THE REPUBLIC OF INGUSHETIA 1994. (February 27, 1994). Available online. In: docs.cntd.ru/document/720705885. Consultation date: 12/04/2020.

THE CONVENTION ON HUMAN RIGHTS AND FUNDAMENTAL FREEDOMS OF THE COMMONWEALTH OF INDEPENDENT STATES. 1995. (November 5, 1995). Federal Law no. 163-FZ. Available online. In: docs.cntd.ru/document/1900703. Consultation date: 12/04/2020. 
Gyulnaz Eldarovna Adygezalova, Irina Stanislavovna Kich, Sergey Alekseevich Zhinkin, Susanna Vladimirovna Salikova y Neonila Dmitrievna Paltseva

810

Role of principles of law from the perspective of legal impact in modern Russia: theoretical and technical-legal aspects

THE LAW OF KABARDINO-BALKARIAN REPUBLIC No. 52-RZ. 2002. (August 3, 2002). On legal acts of the Kabardino-Balkarian Republic. Available online. In: docs.cntd.ru/document/802054266. Consultation date: 12/04/2020.

THE LAW OF KRASNODAR KRAI NO. 7-KZ. 1995. (June 6, 1995). On lawmaking and laws and regulations of Krasnodar Krai. Available online. In: docs.cntd.ru/document/461607123. Consultation date: 12/04/2020.

THE LAW OF THE REPUBLIC OF KALMYKIA NO. 2007. 381-LLL-3. (October 1, 2007). On culture. Available online. In: docs.cntd.ru/ document/819018114. Consultation date: 12/04/2020.

THE LAW OF THE REPUBLIC OF NORTH OSSETIA-ALANIA No. 36-RZ. 2014. On laws and regulations of the Republic of North Ossetia-Alania. Available online. In: docs.cntd.ru/document/423857869. Consultation date: 12/04/2020.

VAGINA, Natalia Mikhailovna. 2004. Principles of public law: Abstract of a Ph.D. thesis in Law. Kazan, Russia.

VEDYAKHIN, V.M; SURKOVA, O.E. 2005. Factors of formation and implementation of the principles of law. Samara, Russia.

VEDYAKHIN, V.M., VEDYAKHINA, K.V. 2002. “The Concept and classification of the principles of law" In: Law and politics. No. 4, pp. 526-546.

ZAGIROV, Z.M. 2017. On the issue of ethno-cultural education in multilingual Dagestan. The collection of materials of the round table "Improvement of legislation in sphere of realization of state language policy. Moscow, Russia.

ZAZYCKI, Valery Ivanovich. 1996. "Legal principles in the legislation of the Russian Federation" In: State and law. No. 11, pp. 122-139. 

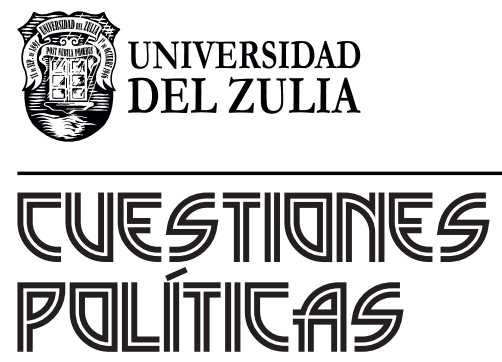

Vol.39 No 68

Esta revista fue editada en formato digital y publicada en enero de 2021, por el Fondo Editorial Serbiluz, Universidad del Zulia. Maracaibo-Venezuela 